\title{
REFLECTIONS \\ Reflections on HIV care and ART - a view from Pietermaritzburg
}

\author{
C Armstrong, BSc (Hons), MB ChB, MRCP (UK), DTM\&H, DA (SA), DipHIVMan
}

Corresponding author: C Armstrong (carolinejarmstrong@gmail.com)

Dr Caroline Armstrong hails from Edendale Hospital in Pietermaritzburg, KwaZulu-Natal Province, South Africa

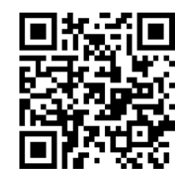

I held her hand; her wasted arm revealing the anatomy of every bone and muscle. Her eyes were closed, weighed down by the burden of disease. She lay upon the bed in my consulting room and there, with no fanfare, she breathed her last breath, passing effortlessly from life into death. Ironically, it was 1 December 2000, World AIDS Day. The patient was a nursing sister and her decline in the face of no antiretroviral therapy (ART) had been harrowing. At times like these, the futilty of working in an HIV clinic was overwhelming, and I fought tears as I turned with a heavy heart to deal with the devastated family as best I could.

I had arrived in KwaZulu-Natal from my native Britain in 1997 to work for two years. I soon realised that the numbers of HIVinfected people were growing inexorably, but that no-one really knew what to do with those individuals who had summoned the courage to take an HIV test and had a positive result. Tripledrug ART was new, even in Europe, and virtually unheard of in the hospitals in which I was working. Knowledge about the natural course and management of HIV was limited, even among healthcare professionals.

On the wards if a patient had 'the label' (coded in various subtle ways in the doctors' notes), then doctors and nurses would often not fully address whatever the presenting problem was even if it was unrelated to HIV. There would be hushed tones on the ward round, a shrugging of shoulders and a general feeling that there was nothing much more that could be done. Little wonder that time and again patients would refuse to be tested, even in the face of all the stigmata of advanced HIV infection. Because, at that time, to test positive meant that your medical team might have looked no further for what was actually wrong with you. In effect, you would have been sent home to die.

It seemed that we doctors hated the diagnosis almost as much as the patients did. It called us failures; it labelled us as incompetent, inept, ineffectual; it mocked our training and humbled us as we fought to cope with the burgeoning numbers inundating our services. We had no oral antifungal agents just gentian violet. Amphotericin B was extremely difficult to obtain and cryptococcal meningitis, when the diagnosis was actually made, was almost universally fatal. There were virtually no HIV services, and patients were often literally neglected as they trod the terrifying path of opportunistic infections to their death.
In 1999, I started working at a government hospital in Pietermaritzburg. There, an insightful and committed physician had started an HIV clinic (one of the first in KwaZulu-Natal) and I remember clearly how incredulous and excited I was about this! Someone was willing to see these patients; someone actually wanted to see these patients! Someone felt they had something to offer in the face of the HIV monster which had thus far defeated all the doctors I knew! I was captivated by the thought and it was not long before I joined the clinic. Although we had no antiretrovirals (ARVs), we provided something that these patients hadn't hitherto experienced: a place where they were welcomed because of their HIV status.

\section{'It seemed that we doctors hated the diagnosis almost as much as the patients did. It called us failures; it labelled us as incompetent, inept, ineffectual; it mocked our training and humbled us as we fought to cope with the burgeoning numbers inundating our services.'}

Elsewhere in society and in the healthcare system at that time, people living with HIV were rejected and ostracised. But in an HIV clinic, they were embraced. We got to know and care about our patients; we treated their opportunistic infections; we obtained disability grants for them; and we spent many hours counselling about death and dying, allowing people to explore and verbalise their fears. We encouraged mothers to make memory boxes for their children and we galvanised patients to put their affairs in order before they died.

We tried to read as much as we could about HIV management; we gave isoniazid and cotrimoxazole prophylaxis and we obtained a supply of ketoconazole for oesophageal candidiasis. There were so many things we didn't know. The internet was limited and we relied heavily on our manuals to teach ourselves HIV medicine. It became increasingly obvious that ARVs were going to be the only solution for our burdened country. How many heated discussions were had around this topic! Many people felt that such an expense could never be borne by a middle-income country with such a vast HIV epidemic. 


\section{'Although we had no antiretrovirals, we provided something that these patients hadn't hitherto experienced: a place where they were welcomed because of their HIV status.'}

In 2000, we started prescribing the cheapest ARV drugs in a desperate attempt to do something that could slow down the disease progression. And so Bongani, weak and wasted, with histoplasmosis of the palate, was our first patient to receive didanosine (which he paid for) and hydroxyurea (which we supplied). Amazingly, he blossomed on what is now considered substandard, toxic dual therapy, and we marvelled in wonder at his improved health! This was the first time we had ever seen the disease checked and reversed.

Next, didanosine and stavudine became available for US $\$ 1$ per day. This was affordable to a number of patients and it worked! It was relatively durable and we saw people rally. Very few people in South Africa at this time knew much about HIV treatment. We constantly felt like isolated and lonely pioneers, chasing the pipedream of triple therapy. Those were the days when the government dragged its collective feet in almost everything concerning the treatment of HIV and the Treatment Action Campaign had to force them into the courts.

Later, the advent of relatively cheap efavirenz meant that at last we could initiate patients on really effective ART. The caveat of course was that they had to pay R700 for one month's supply. Those who could afford it sat side by side with those who couldn't, which was a huge source of frustration for all of us. We continued to be astounded by the effect that these drugs had on our patients. After so many years of losing countless lives, at last we had a weapon with which to fight back, and it was a glorious feeling. We still lacked adequate monitoring (it was difficult to convince people to spend R750 testing their viral load privately) and we learnt hard lessons as we saw peripheral neuropathy, lactic acidosis and drug-related deaths.

Early in 2003 the air was thick with rumours that soon the government would introduce a national ART programme. When the moment actually arrived, it was a cause of great celebration. The package was comprehensive and at last we could monitor patients' responses to therapy. Our KwaZulu-Natal Department of Health seemed really committed, with our Minister of Health, Dr Zweli Mkhize, even coming to work at the clinic on Monday mornings!

\section{'After so many years of losing countless lives, at last we had a weapon with which to fight back ...'}

I still work with HIV - having been privileged to have witnessed the enormous mobilisation of resources and commitment that has brought us to where we stand today as a country. The HIV story of South Africa continues to evolve, but for me, the battle will never be as fierce again.

S Afr J HIV Med 2014;15(1):16-17. DOI:10.7196/SAJHIVMED.1033 